
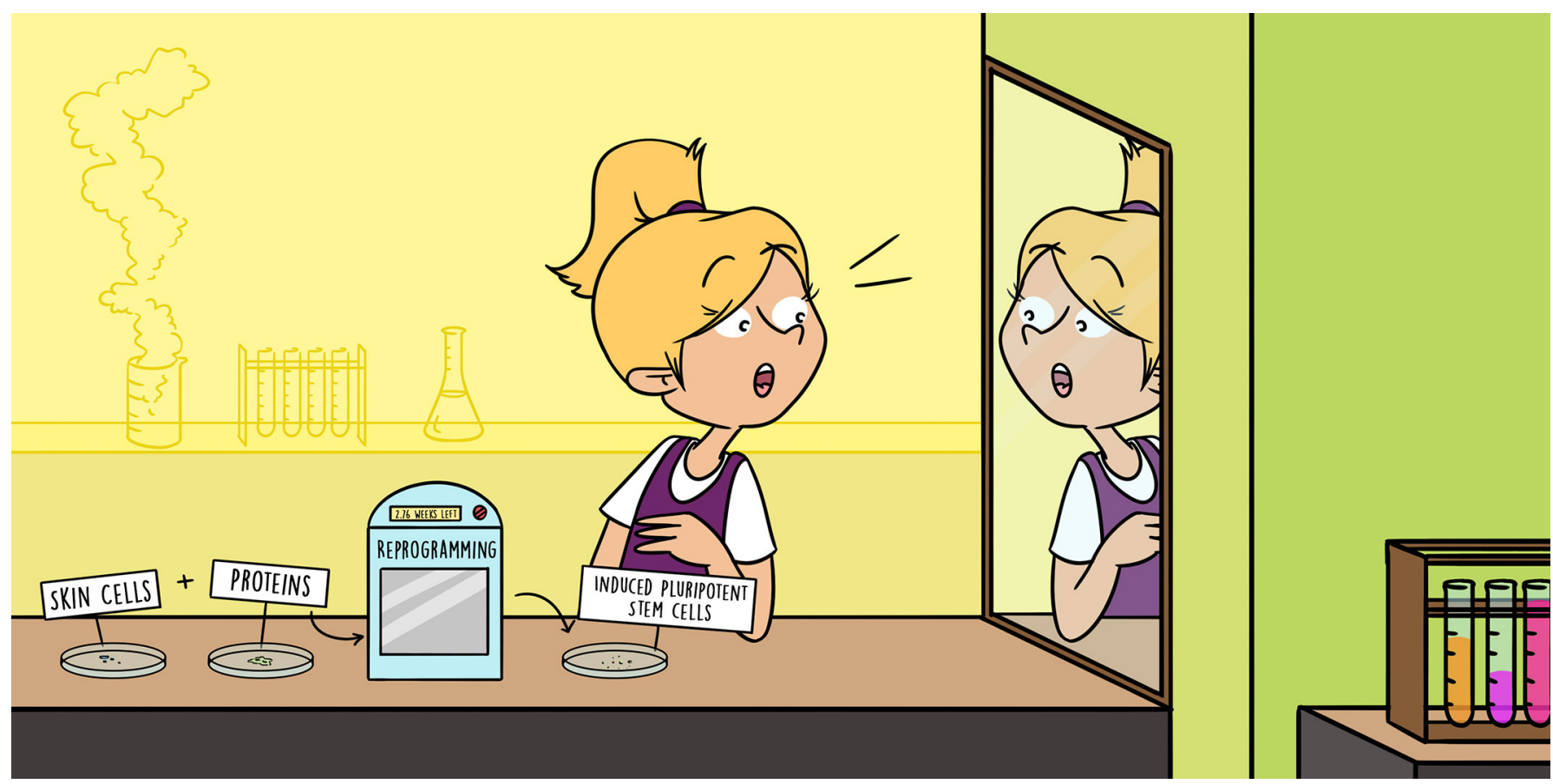

\title{
WHAT ARE EMBRYONIC STEM CELLS AND HOW CAN THEY HELP US?
}

\section{Eran Meshorer *}

Department of Genetics, The Institute of Life Sciences and The Edmond and Lily Safra Center for Brain Sciences, The Hebrew University of Jerusalem, Jerusalem, Israel

YOUNG REVIEWERS:

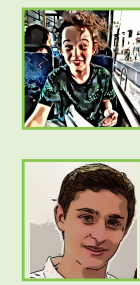

\section{OMER}

AGE: 11

YONATAN

AGE: 14
All living things, including humans, are made of cells. Each tissue and organ of the body contains cells that are specialized to perform specific jobs - the liver contains liver cells, the brain contains neurons, the eyes contain light-detecting cells, and so on. But all human life begins with the encounter between two cells: the sperm cell from the father and the egg cell from the mother. Fertilization occurs when the sperm cell meets the egg cell. The fertilized egg cell divides into two cells. Each cell then divides into two additional cells and so on until, after a few days of cell division, a tiny embryo develops. In the early stages, the microscopic embryo is made up of cells that have the potential to develop into all types of cells. Scientists managed to grow these embryonic cells in the lab, and named them embryonic stem cells (ESCs). While ESCs offer promising and exciting opportunities, like the possibility of growing organs in the lab, the production of ESCs requires human embryos, which involves many technical and ethical problems. In 2007, researchers found a way to produce human cells with the abilities of ESCs by reprogramming regular cells so that 
FERTILIZATION

The encounter between the sperm cell and the egg cell. From the moment of fertilization, embryonic development begins. An egg with no sperm is an unfertilized egg.

\section{DNA}

The genetic material that is responsible for the characteristics of organisms. For example, a certain area in the DNA is responsible for the color of the eyes, another for the color of the skin, etc.

\section{PLURIPOTENCY}

A feature of embryonic stem cells that means the ability to transform into every type of cell. "Pluri" means "a lot" and "potent" means "ability," so pluripotent means "very-capable."

\section{IN VITRO}

FERTILIZATION (IVF)

When an egg cell is met with a sperm cell in the lab, outside of the body.

\section{EMBRYONIC STEM} CELLS (ESCS)

Cells taken from a 1-week old embryo. These cells have two special features: they can divide in an unlimited way under certain conditions, and they can become all types of cells

\section{DIFFERENTIATION}

A process in which a stem cell transforms into a mature cell.

\section{they become stem cells. Today, scientists can change almost every type of cell into almost every other type of cell!}

\section{IT ALL BEGINS IN FERTILIZATION, WHEN THE SPERM MEETS THE EGG}

Embryonic development begins the moment of fertilization, when the sperm meets the egg (Figure 1). Fertilization brings together the genetic material (DNA) from both parents, half from the egg and half from the sperm, and this combination of genetic material produces the embryo. From the moment of fertilization, the fertilized egg goes through a process of cell division. The fertilized egg first divides into two cells, then each of these divides into two more cells and so on until, a few days later, we have a small ball made up of a few dozen embryonic cells. About a week after fertilization, the developing embryo looks like a hollow ball of cells, which will later become the placenta, and an internal pile of cells, which will become the embryo itself (Figure 1). Since this small number of cells will become a complete baby, these early cells must have the ability to become every cell in the body, like skin cells, muscle cells, liver cells, or brain cells. Because of this ability, these cells are called pluripotent ("pluri" = a lot; "potent" = ability). About a week after fertilization, the embryonic cells gradually lose their pluripotency and gradually become the various tissues and organs. So, there is a relatively narrow window during which pluripotent ESCs exist in the embryo.

In 1998 scientists from the U.S. and Israel first managed to grow pluripotent cells from human embryos in the lab. They worked with embryos that were created by in vitro fertilization (IVF), which is a process that allows couples that experience difficulty getting pregnant to have children. At the end of the IVF process, doctors are usually left with many 1-week-old embryos that are no longer needed. These tiny embryos can be used for research, and scientists used them to figure out how to grow pluripotent cells in the lab (Figure 2). These cells are called embryonic stem cells (ESCs).

Unlike cells in the embryo itself, ESCs grown in the lab can stay in their pluripotent state if the right growth conditions are present. These cells divide about once a day so, over time, scientists can grow millions or billions of ESCs. If the growth conditions for the ESCs are changed appropriately, scientists can stimulate the ESCs to go through a process called differentiation, in which the ESCs can develop into any of the different cell types present in the body! Scientists have been working on this amazing project for more than 20 years!

The production of ESCs from human embryos is both technically difficult and ethically complex. Therefore, many efforts have been made to produce pluripotent stem cells from other cells, to avoid the 
Figure 1

Early embryonic development and pluripotent cells. On the left, you can see the egg and the sperm prior to fertilization. Once the two meet, the egg is fertilized and starts to develop. About 1 week after fertilization, cell division has created a tiny embryo containing outer cells that will become the placenta (gray-blue), and inner cells that will become the embryo (yellow). If fertilization happens outside of the body (in vitro fertilization), it is possible to remove the internal cells of the embryo at this stage and grow them in the lab. If they successfully grow, they are called embryonic stem cells (ESCs).

\section{CLONING}

A process in which the DNA of a mature cell is injected into an empty fertilized egg after it has been emptied of its DNA and the DNA of the sperm cell. If this egg is returned into the animal, the baby will be genetically identical to the cell from which the DNA was taken.

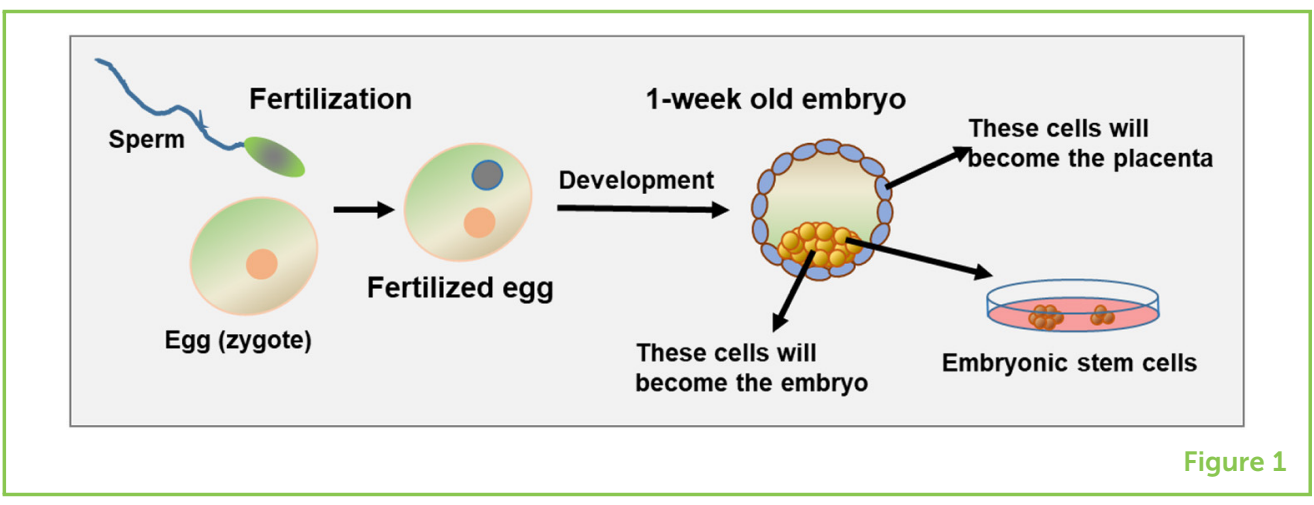

use of actual embryos. The idea is to reprogram mature cells to turn them back into stem cells.

\section{CLONING}

The first attempts to turn mature cells back into pluripotent stem cells involved a process called cloning. In the cloning process, an egg is fertilized in the lab, and right after fertilization, the DNA is removed from the egg. The empty egg is then injected with DNA from another mature cell, such as a skin or blood cell. Even though the DNA is from a mature cell, the environment of the egg will basically reprogram the genetic material from the mature cell, so that it can create an embryo. If the egg keeps developing, it will develop into a clone of the person or animal from which the mature cell was taken. Human cloning is illegal, but in the early 1960's, English researchers successfully cloned frogs. Frogs have relatively very large eggs, so they are easy to work with. The researchers took a fertilized egg from a frog, removed the DNA, and injected the egg with genetic material from an intestinal cell of another frog. After about 40 days, the egg matured and developed into a tadpole. The tadpole was genetically identical to the frog from which the intestinal cell was taken. Soon, some labs started performing this process in mammals, but the early attempts at this process failed. After 30 years of failed attempts, in 1996, researchers from Scotland successfully cloned a sheep named Dolly (Figure 3A), proving that cloning is also possible in mammals. Since the end of the 1990's, a wide variety of animals has been successfully cloned, including mice, rabbits, cows, pigs, horses, donkeys, camels, and even a type of endangered wolf. The famous singer Barbara Streisand, who felt very sad when her dog died, payed researchers a large amount of money to clone two puppies identical to the original dog! In 2018, macaque monkeys were cloned successfully for the first time (Figure 3B), and in 2019, the Chinese police announced the cloning of a police dog that has since started to take a training course.

\section{THERAPEUTIC CLONING}

As we mentioned, human cloning is illegal, but a procedure called therapeutic cloning is allowed, meaning cloning for medical purposes. 
Figure 2

Microscope image of human ESCs. ESCs grow as a cluster of cells, which can be seen in the middle of the figure. Around this cluster are darker cells supporting the growth of the ESCs, which are called support cells.

Figure 3

(A) Successful cloning of mammals. Dolly the sheep, the first successfully cloned mammal, was cloned in Scotland in 1996. Dolly is shown with her first offspring, Bonnie (left). (B) The first cloned monkeys, Hua Hua and Zhong Zhong, were successfully cloned in China in 2018.

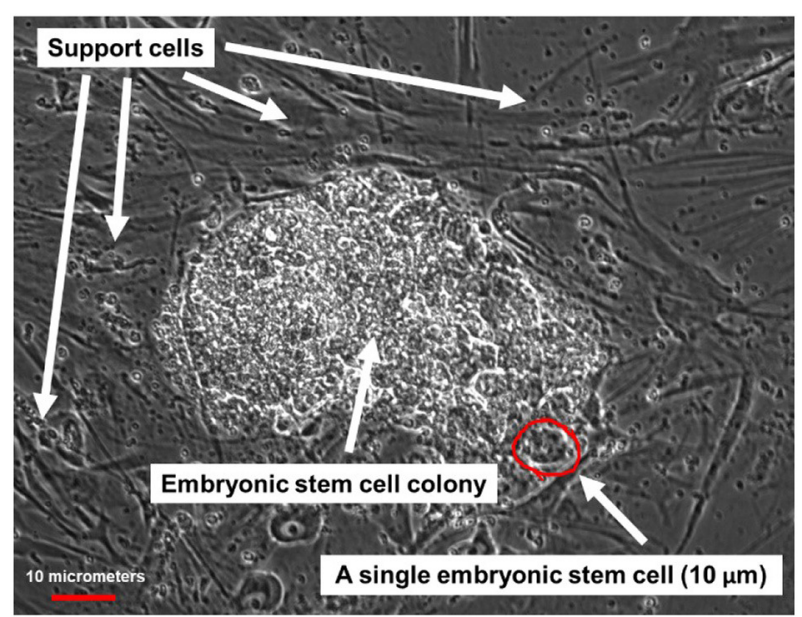

Figure 2

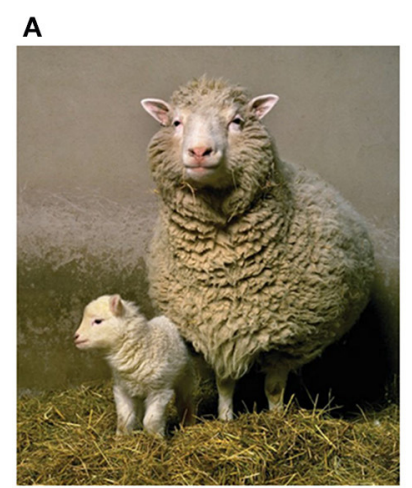

8

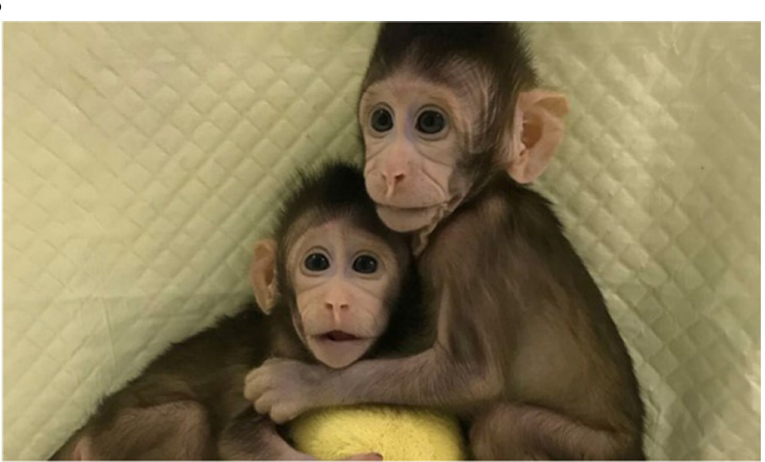

Figure 3

The same procedure described above for frogs is performed on fertilized human eggs, which are emptied and injected with genetic material from another cell, usually a skin or blood cell. After about a week, pluripotent cells are removed and used to grow ESCs. These ESCs contain the DNA of the person from which the skin or blood cell was taken. In this way, it is possible to produce ESCs from any living person! This means that, in the future, when we know how to produce tissues, such as liver tissue from ESCs, it might be possible to grow new organs to use for transplants. The big advantage in using genetically identical cells for transplants is that the immune system does not see the transplanted organ as foreign and therefore will not attack it the same way it would attack an organ from a genetically different individual. This prevents many problems and complications.

\section{REPROGRAMMING}

Therapeutic cloning might sound like a great thing, but this procedure is very problematic and complex. Moreover, it requires using eggs, which are very hard to get. But, in 2007, Japanese researchers found an amazing way to transform mature cells, like skin or blood cells, directly 


\section{REPROGRAMMING}

A process in which regular, mature cells are transformed back into pluripotent embryonic stem cells. into stem cells without using eggs! They found a combination of proteins that, if injected into the mature cells, gradually reprogrammed the mature cells into stem cells. This procedure is much simpler than cloning and every lab can quite easily produce stem cells from almost every type of cells. This process is called reprogramming, and the cells produced are called induced Pluripotent Stem Cells (iPSCs).

\section{THERAPY?}

The hope is to be able to use both types of stem cells, both embryonic and induced, to treat diseases that are caused by the death of cells in the body. For instance, in type 1 diabetes, the beta cells in the pancreas die. Beta cells are responsible for producing the hormone insulin, which helps the tissues to absorb sugar from the blood to provide the body with energy. Children who are born with type 1 diabetes eventually lose all of their beta cells and stop producing insulin. Since it is impossible to live without insulin, these children must get insulin injections every day. A few research groups are trying to transform ESCs into beta cells that can be transplanted into diabetes patients, so that the patients can produce insulin again. This is a big dream because, as of today, there is still no successful treatment based on transplanting cells grown from stem cells, even though there are experiments in humans currently going on. In one of these experiments, neurons prepared from ESCs are being transplanted into the brains of patients with Parkinson's disease, in which certain brain cells die. In a second experiment, retina cells are being transplanted to patients suffering blindness caused by a disease that results in the loss of cells in the eye.

Hopefully, in the coming years, researchers will successfully produce more and more types of cells and even organs from embryonic or induced pluripotent stem cells. This will lead to more and more successful trials in humans, so that it will be possible to treat and even cure a large number of diseases in which cells of the body die, or that require replacement of organs.

SUBMITTED: 25 January 2020; ACCEPTED: 03 March 2020;

PUBLISHED ONLINE: 30 March 2020.

EDITED BY: Idan Segev, Hebrew University of Jerusalem, Israel

CITATION: Meshorer E (2020) What Are Embryonic Stem Cells and How Can They Help Us? Front. Young Minds 8:32. doi: 10.3389/frym.2020.00032

CONFLICT OF INTEREST: The author declares that the research was conducted in the absence of any commercial or financial relationships that could be construed as a potential conflict of interest.

COPYRIGHT (c) 2020 Meshorer. This is an open-access article distributed under the terms of the Creative Commons Attribution License (CC BY). The use, distribution 

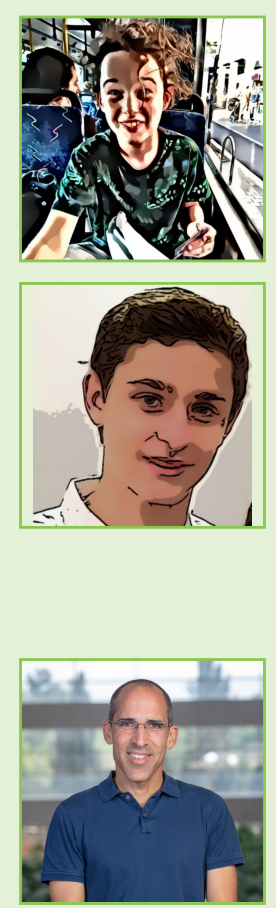

or reproduction in other forums is permitted, provided the original author(s) and the copyright owner(s) are credited and that the original publication in this journal is cited, in accordance with accepted academic practice. No use, distribution or reproduction is permitted which does not comply with these terms.

\section{YOUNG REVIEWERS}

\section{OMER, AGE: 11}

I like to read history and biology books, and play Pokémon games and other Nintendo Switch games.

\section{YONATAN, AGE: 14}

I live in Tel Aviv with my parents, and with my younger sisters and brother, no dog. I like to discover new things, to learn about cool stuff, from ancient history to present day science. When worse comes to worst, I play basketball.

\section{AUTHOR}

\section{ERAN MESHORER}

Prof. Meshorer completed his Ph.D. at the Hebrew University and performed his post-doctoral studies at the National Cancer Institute, NIH. In 2007 he returned to the Hebrew University and is currently heading the "Epigenetics, stem cells, and neurons" laboratory in the Department of Genetics and the Edmond and Lily Center for Brain Sciences (ELSC). Meshorer's research focuses on chromatin plasticity and epigenetic regulation in embryonic and neuronal stem cells, during reprogramming, and in pluripotent models of neurodegenerative diseases, as well as epigenetics of archaic genomes ("paleo-epigenetics"). *meshorer@cc.huji.ac.il 